throws on a number of distinguished investigators sidelights which never made the pages of a text book; Sir William Thomson, for example, is characterised not only as a designer of precision electrical instruments but also as the inventor of a patent water tap. What's more, a good many of the old masters' experiments are reproduced as working models, in the museum's push-button tradition, though the precise value of the demonstrated principle is not always made clear. Kelvin's water dropper, for example, is a pleasant enough looking contraption which intermittently interrupts two streams of water, sends out a spray of droplets and emits a blue spark. An attached rubric explains that this electrostatic induction machine had no practical application, although it led to the design of the Replenisher and the Mouse Mill Generator. Which is all very well if you are acquainted with mouse mill generation, and know its significance (or otherwise).

In fact, as soon as the Victoriana has been digested, the exhibition is plainly a display for the specialist, and calculated to suffuse the museum's staple schoolboy customer with indifference. The explanation of the Josephson effect might well have bcen written in a foreign language and when a layman looks at a superconducting solenoid it does not really help to know that it has a field of 5.4 tesla with a current of $2,300 \mathrm{~A}$. It does not even help to be told that you are looking at a superconducting solenoid. Similarly, two historic pieces of apparatus from the Cavendish Laboratory fall on stony ground if you have not the first idea of what bombardment means, or why it is nice to see the paths of atoms traced in a cloud chamber. C. T. R. Wilson's cloud chamber, described by Rutherford as "the most original and wonderful instrument in scientific history" does not begin to look as though it deserves such a testimonial, and neither does the written explanation supply a justification. A group of youngsters perusing the show on opening day gave about five seconds each to telephones through which one could hear the voices of Wilson and Rutherford describing their work. Five seconds was really not long enough to catch their drift but it was just about long enough to establish that you did not really understand what they were talking about.

So, if you are a physicist, this is an exhibition which you will discover to be packed with nostalgic gadgetry ( $p a c e$ Wilson and his cloud chamber) and if you are not a physicist it is an exhibition which tells a tale of the sound and the fury (disintegrating the nucleus of an atom surcly qualifies for that description), but may not signify too much. The title of the show springs from the fact that during the first decade of its existence the most striking foreign discovery that the Physical Society saw was Edison's phonograph; a highlight in recent times was a demonstration of Gabor's Nobel prizewinning holograph. And there at the entrance to the exhibition sits a holograph of Gabor himself, looking for all the world like a Tussauds version of the multiple murderer Reginald Christie. Two more exhibits which deserve mention as eye-catching and reasonably selfexplanatory spectacles are a scanning electron misroscope (the Cambridge Stereoscan 600 , whose blown-up pictures would have looked all that much better in colour) and a pair of motorised mirrors which track back and forth on rails in an experiment measuring the velocity of light. On the whole, this exhibition supplements Rutherford's definition of all science being either physics or stamp collecting. It is also semantics.

\section{First Australian-Soviet science agreement}

\section{Peter Pockley, Sydney}

THE first agreement between Australia and the Soviet Union for cooperation on science and technology was initialled in Canberra at the end of February. At this stage the formal agreement has been expressed only in the most general terms.

A delegation of three Soviet science administrators paid a preliminary visit to Australia to discuss possible projects of cooperation. The Soviet delegation was at a high level-representing the State Committee, USSR Council of Ministers for Science and Technology were Mr L. N. Yefremov (First Deputy Chairman) and Mr V. A. Kuzin (Head of the Department of Foreign Relations) ; representing the USSR Academy of Sciences was Mr S. G. Korneev (Chief of the Directorate of Foreign Relations).

The agreement is seen as a quiet first, but significant, step in the Australian Labor government's diplomatic moves to equalise, as far as possible its formal relations between the western, eastern and Asian blocs. Australia has had a binational agreement with the United States for scientific and technical cooperation since 1968. Australian science also has strong links with Britain through the Anglo-Australian Telescope Board and a cooperative programme with $\mathrm{Ja}$ pan for its geostationary meteorological satellite is being evaluated. Soviet and Australian scientists will now work towards the signing of a detailed agreement in Moscow later this year. The Australian Department of Foreign Affairs has recently appointed its first
Senior Adviser on Science, Technology and the Environment, Mr Guy Gresford, an Australian who was formerly Director of Science and Technology at the United Nations.

\section{Linear motors and the EEC}

\section{John Wilson}

EIgHT manufacturers of linear motors met recently in Brussels, at the request of the Commission of the European Communities, to work out joint proposals for the development of a high power motor suitable for a fast European inter-city transport system.

The companies, representing France, West Germany and the United Kingdom, outlined suggestions for future research but also indicated that the commission must identify the objectives of such a programme more precisely before close collaboration can begin. It is now up to the commission to assess the opinion of the various governments and transport authorities concerned and produce some formal proposals with which the manufacturers can come to grips.

The commission feels strongly that any inter-city transport system for the 1980 s, which would involve travel at speeds $>300 \mathrm{~km} \mathrm{~h}^{-1}$, should be planned on a European basis. Whatever means are used to support the vehicle-wheels, jets of air or magnetic suspension-a high power linear motor is the obvious choice for the traction unit as it overcomes the mechanical difficultics of transmitting sufficient force to the track.

The 'club' of manufacturing companies, including Tracked Hovercraft, General Electric Traction and Linear Motors, first met in June last year and expressed their readiness to embark on a cooperative venture. According to the commission, a good deal of quiet consultation took place afterwards, and that formed the basis of the recent proposals. These are that three cross-company research teams should study the synchronous, asynchronous and transverseflux motors, respectively; another should examine the problems of collecting electric current at high specd; and a fifth should investigate control systems for the motor.

At first there would be some parallel development of all the motors until a particular type or types were chosen for construction. Then these would be built and tested to evaluate the design.

But these proposals represent a very cautious stage in the negotiations between the members of the club because, although the commission tentatively estimates that it will spend about $£ 2$ 